\title{
The Use of Augmented Reality Cards to Improve Science Learning Outcomes About the Effect of Force on The Shape and Motion of Objects
}

\author{
Inge Nur Indah Sri Rejeki Ratna Ningsih \\ Program Studi Pendidikan Sekolah Dasar, Fakultas Ilmu Pendidikan, Universitas Hasyim Asyari, Indonesia \\ Email: artikelindahnur.98@gmail.com
}

\section{A R T I C L E I N F O \\ Article history: \\ 1 Mei 2020 Received in \\ revised form \\ 11 Juni 2020 \\ Accepted 10 Juli 2020 \\ Available online 25 Agustus 2020 \\ Kata Kunci: \\ Kartu Augmented Reality, hasil belajar}

Keywords:

Augmented reality card,

Learning outcomes

\begin{abstract}
A B S T R A K
Pembelajaran Ilmu Pengetahuan Alam Sekolah Dasar Negeri Kepanjen II Kecamatan Jombang di kelas IV pada materi pengaruh gaya terhadap bentuk dan arah gerak benda, mengalami masalah berupa sulitnya pemahaman materi oleh siswa. Dari hasil evaluasi pembelajaran menunjukkan bahwa hanya $55 \%$ dari 30 siswa memperoleh nilai di atas KKM yang telah ditentukan sebesar 75,0. Berdasarkan masalah yang terjadi, maka peneliti merencanakan perbaikan pembelajaran 2 siklus. Pada tahap perencanaan yang dilakukan adalah menganalisis KI dan KD, membuat indikator, tujuan pembelajaran dan dilanjutkan dengan menyusun rencana pelaksanaan pembelajaran serta menyusun instrumen penilaian pembelajaran. Terakhir pada tahap perencanaan ialah membuat media pembelajaran yakni aplikasi Augmented reality. Pada tahap pelaksanaan pembelajaran mengalami peningkatan baik aktifitas guru maupun aktifitas siswa. Secara keseluruhan peningkatan aktifitas guru meningkat dari $70 \%$ menjadi $80 \%$. Sedang aktifitas siswa meningkat dari $72 \%$ menjadi $90 \%$. Hasil belajar sebelum menggunakan media kartu Augmented Reality ketuntasan klasikalnya 55\%. Hasil belajar siswa pada pembelajaran siklus I ketuntasan klasikalnya $63 \%$ dan siklus II mengalami peningkatan menjadi $84 \%$.
\end{abstract}

\begin{abstract}
A B S T R A C T
The Science Learning of Kepanjen II Elementary School, Kecamatan Jombang, in the fourth grade on the effect of force on the shape and direction of motion of objects, experienced problems in the form of difficulty understanding the material by students. The results of the learning evaluation show that only $55 \%$ of the 30 students scored above the predetermined KKM of 75.0. Based on the problems that occur, the researchers plan to improve learning in 2 cycles. At the planning stage, it is carried out by analyzing $\mathrm{KI}$ and $\mathrm{KD}$, making indicators, learning objectives, and continuing with compiling a lesson plan implementation and developing learning assessment instruments. Finally, in the planning stage, it is to create learning media, the Augmented reality application. At the implementation stage of learning has increased both teacher activities and student activities. Overall, the increase in teacher activity increased from $70 \%$ to $80 \%$. Meanwhile, student activity increased from $72 \%$ to $90 \%$. Learning outcomes before using Augmented Reality card media classical completeness of 55\%. The results of student learning in the first cycle of classical completeness of $63 \%$ and the second cycle has increased to $84 \%$.
\end{abstract}

\section{Introduction}

Natural Science or often called IPA is a field of science that discusses nature and its components in nature. Recently, science has grown, not only discussing nature but starting to invite students to have a scientific mindset and carry out a scientific process in science learning activities. This statement is in line with Nash's statement (Asmoro \& Mukti, 2019; Fitriyati et al., 2017) Science is "a way or method to observe analytical nature, complete carefully and connects between other phenomena so that the whole forms a new perspective on the object. being observed". Based on this statement, IPA also shows that science is very close to humans and exists in humans themselves. Seeing this, science began to be taught from an early age, science learning was obtained by students through school. Science learning in schools is carried out by paying attention to the objectives of science learning, the goal is to instill curiosity and a positive attitude towards science, technology, and society, develop process skills to investigate the natural surroundings, solve problems and make decisions, develop natural phenomena, so that students can think critically and objectively (Aningsih \& Zahrani, 2019; Elyana, 2017). (Mardiana, 2018; Pindo \& Rinci 2018) also stated that science subjects aim to make students have the following abilities; 1) Obtaining belief in the greatness of God Almighty based on the civility, beauty, and order of His creation. 2) Develop knowledge and understanding of science concepts that are useful and can be applied in everyday life. 3) Develop curiosity, a positive attitude, and awareness of the interplay between science, environment, technology, and society. 4) Developing process skills to investigate the environment, solve problems and make decisions. 5) Increase awareness to participate in maintaining, maintaining, and preserving the natural environment. 6) Increase 
awareness to respect nature and all its regularities as one of God's creations. 7) Obtain knowledge, concepts, and science skills as a basis for continuing education to junior high school.

In addition to paying attention to objectives, science learning in elementary schools must be conveyed properly so as not to confuse students because of abstract thinking. This opinion was obtained from Piaget's statement (Bujuri, 2018; Juwantara, 2019; Suandito, 2017) he stated that students aged 6-12 years are at the concrete operational stage. The concrete operational stage means students need close and real examples to learn from. To achieve this, learning media are needed to help students during learning. Media in science learning is also very important so that students' knowledge and understanding of these natural phenomena becomes more certain. However, in reality, the use of instructional media is still not considered necessary by teachers. This statement is supported by the results of observations made on natural science learning on the effect of force on the shape and direction of motion of objects in fourth grade Kepanjen 2 Jombang Elementary School. Students found some problems in the form of difficulty understanding the material, this is evidenced by $55 \%$ of the 30 students getting a score above the predetermined KKM, which is 70.0. (Riyanti \& Setyami's research, 2017) found that the media provided by schools was not used by teachers, even stored in the laboratory. (Karlina's research, 2017) found a similar phenomenon, teachers feel that the best media that can be used in learning is themselves. The teacher does not consider other assistive media to be media that can support the effectiveness and efficiency of the learning process in the classroom. If this continues and continues to be allowed to do so, the expected learning outcomes will not reach the target. The quality of learning will not reach the quality expected. Over time, the quality of student and teacher resources will decrease.

Based on the explanation of the problem above, one of the solutions applied is to carry out science learning assisted by learning media, the learning media chosen is Augmented Reality (AR) card media. AR card is a variation of Virtual Environment or better known as Virtual Reality. (Setyawan, 2019) in his research explained that students' science learning outcomes increased after applying AR media in learning. Setyawan's research results also show that AR media is good for use as a learning medium both in class and independently by students. (Yuliono et al., 2019) in their research found that AR media can easily visualize what is happening in human digestion. AR media makes it easy for students to understand complex concepts so that it can facilitate and improve the learning process and learning outcomes. The results showed that there was the effectiveness of AR media on students' mastery of the concept of the human digestive system. Virtual Reality technology in its use puts users into a virtual sphere so that users feel the sensation of entering the application environment. AR cards will make virtual images bring to life with the help of applications that utilize a camera. (Setyawan, 2019; Yuliono et al. 2019) explained that "Augmented Reality (AR) technology can combine 3D objects into a real environment using a camera". AR card media was chosen because AR card media can be seen as if it were real and close to students, this will reduce the risk of students thinking abstractly. AR card media also has the advantage of a less complicated manufacturing process. The working principle of Augmented Reality is tracking and reconstruction (Dwi Mukti, 2019; Setyawan, 2019; Yuliono et al., 2019). At first, the marker was detected using a camera. Four components must be considered in terms of the development and use of Augmented Reality: Computer Hardware, Software (Unity), Scanning Tools, Markers.

The first component is the hardware. The hardware used is in the form of laptops and smartphones. Laptops are used as application development tools, while smartphones and tablets are used as the basis on which the application will be implanted or installed (Dwi Mukti, 2019; Prita \& Joko, 2017; Setyawan, 2019; Yuliono et al., 2019). The second component is the software used as an Augmented Reality application software. This application platform runs on the android or IOS OS. The name of the software used is Aurasma HP reveal. This application can be downloaded on the Playstore for free. The third component is a scanning tool or scanner to scan patterns and activate Augmented Reality. A device that can be used as a scanner is a camera from a smartphone that is integrated with the Fuvoria application. Vuforia is an application developed to support the creation of Augmented Reality. Created in the form of an SDK, Vuforia can carry out image recognition in the development of image recognition. The last component is a marker as the point of appearance of the Augmented Reality object. The development of the marker itself requires a pattern formation technique. Patterns can be black and white or nonpattern. Each pattern will first be tested on how compatible and suitable for use as a marker. Markers can also be pictures or picture cards. Marker is a marker with a pattern or code that is recognized by AR applications such as barcode systems. If there is a marker identified or known by the AR application, the program will load a virtual image object from the computer, at the marker position (Dwi Mukti, 2019; Prita \& Joko, 2017; Setyawan, 2019; Yuliono et al., 2019). Based on the explanation above, the objective of this study is to describe the use of Augmented Reality card media and the learning outcomes of science learning the effect of force on the shape and motion of objects to improve student learning outcomes. The specific objectives of this study include describing the planning and implementation of science learning the effect of force on shapes, the motion of objects using Augmented Reality card media to improve learning outcomes of fourth-grade students. 


\section{Method}

Researchers used a classroom action research of Kemmis and Mc Taggart model. In this model, a cycle consists of four components. This classroom action research procedure is: (1) planning, (2) implementing (action), (3) observation, and reflection. The research subjects were fourth-grade SDN Kepanjen II Jombang, Kabupaten Jombang. Fourth-grade students of SDN Kepanjen II with 30 students, 11 males and 19 females. The method used in collecting research subjects is simple random sampling. The data was collected through observation (field notes, student and teacher activity observation sheets, interviews). Researchers also took data through an objective assessment of the results of formative tests. The instrument used in this study was a test. Before being used in the study, the instrument was carried out by expert testing, reliability testing, and validity testing. Based on the calculation of the inter-rater agreement, the expert test index is 1 , which means that the instrument has very high or very good validity. The reliability and validity test of the contents did not find invalid items. All items have a Corrected Item-Total Correlation value below 0.3. All items have a Corrected Item-Total Correlation value above 0.3 and the reliability value shows 0.953 which is included in the very high category. This study was analyzed using quantitative and qualitative data analysis. Quantitative analysis is used to analyze data obtained by students from the learning outcomes of each cycle. Qualitative analysis is to analyze data from meaningful processes that are contextually and in-depth according to the problems studied regarding student learning activities.

\section{Result and Discussion}

This research was conducted in two cycles, each cycle consists of planning, implementing, and measuring learning outcomes. In the first cycle, planning was carried out by: 1) The researcher interviewed with Mr. Mukhamad Janji Haryono, S.Pd. taking place in the teacher room of SDN Kepanjen 2 on Tuesday, February 04, 2020, 2) Analyzing KI and KD to make indicators and learning objectives. Furthermore, compiling a Learning Implementation Plan, 3) Developing the final evaluation instrument of learning that refers to indicators and learning objectives, 4) Compiling Natural Science learning materials which include the definition of force, the effect of force on the motion of objects, the influence of objects on the shape of objects, measuring force, and the size of the force, and the last is 5) Making Augmented Reality media cards.

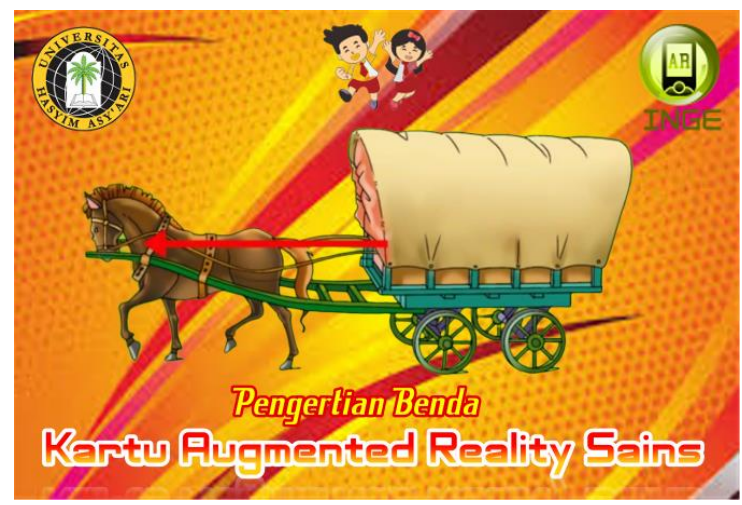

Figure 1. Augmented Reality Card

The first cycle held on Friday, February 14, 2020, for 3 x 35 minutes, started at 07.00 - 08.45 WIB. Learning begins with praying together, led by the class leader. The researcher as a teacher introduced himself and begins to make the class with enthusiastic applause and the jargon "fourth grade is great ...!, fourth grade is amazing ... !!. The teacher was asking and answering questions with the students. The teacher digs up students' memories of the information at the previous meeting. Teachers carry out core activities by guiding students to form groups. Each group consists of 4-5 students. So that with 30 students, 7 groups formed. The teacher explained the steps for group discussion by using a smartphone to run the "INGE AR" application. The first cycle encountered problems when installing the application. In the final activity, the teacher guided students who present the results of the discussion and gave written tests to measure the level of students' understanding of the force and effect material.

From the results of the above observations, it explained that in the first cycle of learning, there are 22 aspects of teacher activity that carried out or the average number obtained was $70 \%$ and $72 \%$ of student activity aspects. Based on the results of observations, the teacher was unable to handle the class during group discussions. The teacher did not provide small group guidance when working on group student worksheets. This results in student 
confusion in doing Augmented Reality card-based assignments. Some of the students ended up getting rowdy by themselves and the group discussion didn't work well. In the presentation session, the voice was not loud enough and the results of the work could not be read by other groups, the presentation of the group work not to be optimal. The results of the learning science subject Force and influence using Augmented Reality Card media has increased from $55 \%$ to $63 \%$. However, the increase in student learning outcomes has not reached the indicator of success, $80 \%$. Therefore, the researcher decided to carry out the second cycle of learning. The percentage change in learning outcomes can be seen in graph 1 .

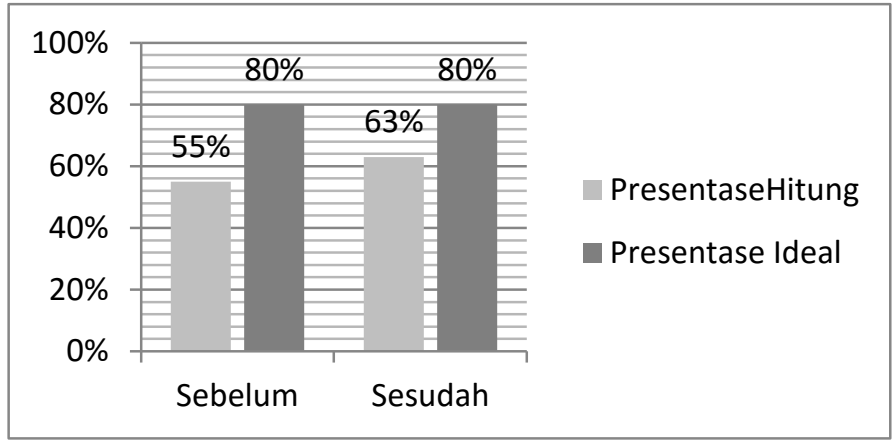

Grafik 1. Hasil Belajar Pada siklus 1

Based on the results of the first cycle, the second cycle of planning was carried out in the form of 1) Reflecting on the learning cycle I with fourth-grade teachers at SDN Kepanjen 2 Jombang, 2) Analyzing KI and KD to make indicators and learning objectives, then compiling a Learning Implementation Plan, 3) Compiling final learning evaluation instrument that refers to indicators and learning objectives, 4) Compiling Natural Science learning materials about its force and effects, 5) Making Augmented Reality card media. Before making Augmented Reality card media, the author interviewed with Mr. Mukhamad Janji Haryono as the fourth-grade teacher about the character of the fourth-grade students of SDN Kepanjen 2 Jombang.

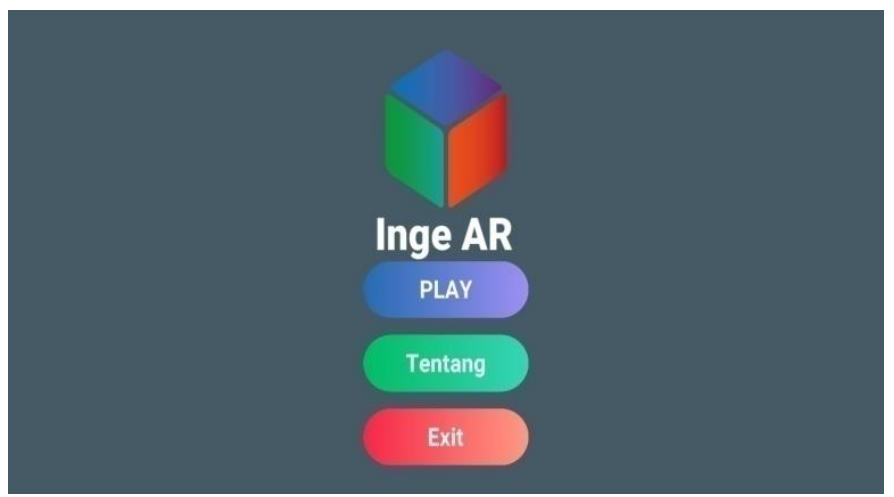

Figure 2. Inge AR application on a smartphone

In the second cycle, which is a follow-up and the result of reflection from the first cycle, the teacher conducts science learning activities with the subject of Force and Effect. The second cycle will be held on Thursday, 20 February 2020 for 3 x 35 minutes, started at 07.00 - 08.45 WIB. Learning began with an initial prayer of learning led by the class leader. The author begins the lesson by conditioning the class through applause and the jargon "Fourth grade is great ..!, four grade is extraordinary ... !!. Researchers perform apperception by asking and answering questions with students. The teacher digs up students' memories of the force information at the previous meeting. The teacher carries out the core activities by guiding students to form groups. Each group consists of 45 students. So that with 30 students, 7 groups were formed. The teacher explains the steps for group discussion by using a smartphone to run the "INGE AR" application. In the second cycle of learning, there were no obstacles because the previous application installation had been carried out. During group discussions, the teacher goes from group to group. So that students do not experience confusion and all group members work according to their 
respective assignments. Learning time goes according to the plan. In the final activity, the teacher guides students who present the results of the discussion and give written tests to measure the level of students' understanding of the force and effect material.

Based on the results of the above observations it is explained that in the second cycle of learning, getting 23 aspects of teacher activity is carried out or the average number obtained is $80 \%$ and student activity is carried out $90 \%$. Based on the results of observations, it was obtained data that the teacher was adept at conditioning the class during group discussions. The teacher provides small group guidance when working on student worksheets in groups. Therefore students in working on augmented reality card-based assignments have no difficulty all group members share assignments and work according to their respective assignments. The learning outcomes of science subject force and their effects using Augmented Reality Card media have increased from 63\% to $84 \%$. The improvement of student learning outcomes has reached a success indicator of $80 \%$. So the researchers considered learning in the second cycle was complete. The increase in learning outcomes can be seen in graph 02.

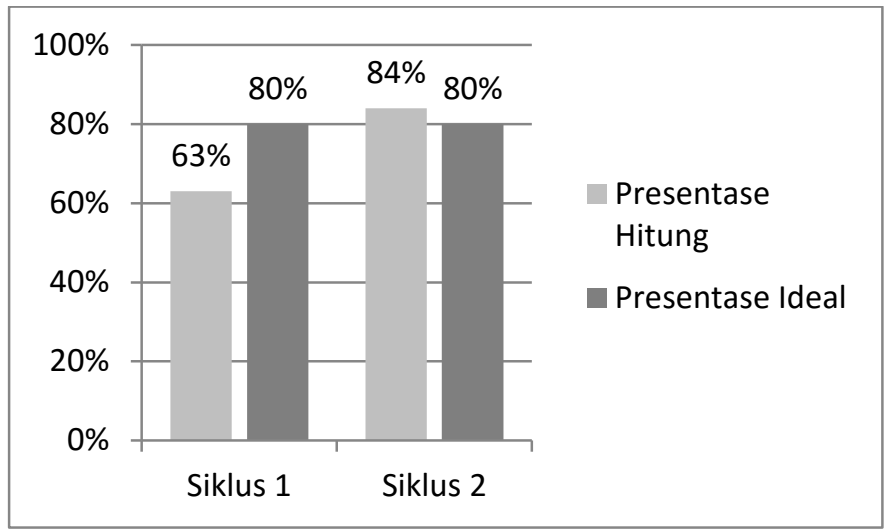

Grafik 2. Hasil Belajar Pada siklus 2

Based on graph 01 and graph 02, it can be said that the use of AR media can improve students' science learning outcomes. The resulting increase was significant because it exceeded the ideal target. The results of this study are in line with research conducted by (Yuliono et al., 2019) stated that AR media can improve science learning outcomes. AR media can become a learning medium to create a practical and fun learning atmosphere and can be accessed anywhere and anytime. Similar to this study, which shows the enthusiasm of students in participating in science learning. AR media is presented in an attractive and interactive packaging so that it can increase students' interest in learning science, especially materials that cannot be seen directly in humans. The difference with this study is that the dependent variable is raised as a problem. However, the concept of variables is still similar, the science subject. Another relevant research result is research conducted by (Setyawan, 2019), in which in his research elementary school science learning outcomes were improved through learning with AR media. In his research, it was explained that students were very interested in science learning which was carried out with the help of AR media. The student's interest makes him serious in following the lesson. This has an impact on increased learning outcomes compared to before. The results of Setyawan's research are similar to this research where students' interest arises because of the help of AR media. AR media makes students focus on the learning process so that learning outcomes also increase. Augmented Reality media can improve mastery of the science concept because it has met several criteria for appropriate learning media. In this case, so that teaching materials can be conveyed effectively, educational technology tools are needed that can spur the concept of learning with holistic, meaningful, authentic, and active criteria (Permana \& Johar, 2014). Besides this, the results of this study are following Piaget's opinion (in Bujuri, 2018; Juwantara, 2019) which states that students aged 6-12 years are at the concrete operational stage. The concrete operational stage means students need close and real examples to learn from. AR media is following this opinion as evidenced by a conducive learning process and attracts students' attention.

The results of this study and the opinion of Piaget (in Bujuri, 2018) indicate that learning carried out by students must be designed according to the level of cognitive, affective, and psychomotor development of students. Therefore, the teacher must be able to create a good learning process that can contain interactive, fun, meaningful, motivating aspects and provide sufficient media and space for students to be able to develop multimedia elements of creativity and independence, according to their talents and interests. learners. In creating a suitable and effective learning process for students, it is necessary to assist with attractive learning media (Fakhrurrazi, 2018; Suwardi 
\& Farnisa, 2018). That is because in learning about science it prioritizes practicum as an application of the theory that has been obtained. Things that need to be considered in media selection are learning objectives, effective, easy to obtain, students, use, not rigidity, cost, novelty value, and quality (Dwi Mukti, 2019; Oktiani, 2017; Riyanti \& Setyami, 2017). By looking at the characteristics of Augmented Reality media, it can train students to think from concrete to abstract (Setyawan, 2019). This excess is needed to understand the complex material of the human body's digestive system.

Based on the description above, AR-based learning media is very important to increase the interest and understanding of students' material regard to the concept of science in general and specifically. The media is not only monotonous with text but also audio/visual and even animation which makes it easier for students to understand the material (Setyawan, 2019; Yuliono et al., 2019). AR learning media is one of the important factors in science learning activities. Through these media, teachers can be helped to deliver the material. Learning activities become more alive with this media. Students also feel the benefits of the media. Following the development stage of students as said by Piaget (in Juwantara, 2019) that in students there are cognitive structures called schemes. In understanding their world, students use schema. Schemes range from simple schemes to more complex schemes. Piaget emphasized (in Suandito, 2017) that two processes are responsible for the way students use and adapt their schemes, assimilation, and accommodation. Assimilation occurs when a student inserts new knowledge into existing knowledge. Accommodation occurs when students adjust to new information, students adjust their scheme to their environment. With a fun learning process, students will more easily understand and remember what they are learning.

This study only used two cycles. The learning outcomes increased twice. Need to be a further cycle in future research. So that, it can measure the increased learning outcomes caused by this AR media. The increase in science learning outcomes in this study is good to classify because the percentage of the learning outcomes is above the ideal presentation by $4 \%$. However, in future research, it is necessary to increase learning outcomes by at least $10 \%$ of the ideal limit. AR learning media can be integrated with a learning model that is even more interesting so that it is expected that percentage of learning outcomes is higher than this study. By looking at the results of this study, teachers should apply Augmented Reality (AR) learning media to increase students' mastery of natural science concepts in any material. Not only in science learning, but other learning is also highly recommended for using this AR media. Other researchers should pay attention to the learning process using AR media with comprehensive observations so that complete research results are obtained between the process and the results of learning.

\section{Conclusion}

The learning process using media is very important to increase interest and understanding of the material. One of them is the use of Augmented Reality (AR) based learning media. The media used is not only monotonous with text, but also contains audio/visual multimedia elements and even animation that makes it easier for students to understand the material. It is supported by the percentage learning outcomes that increase in each cycle carried out. By looking at the results of this study, teachers should apply Augmented Reality (AR) learning media to increase students' mastery of natural science concepts in any material. Other researchers should pay attention to the learning process using Augmented Reality media with comprehensive observations so that complete research results are obtained between the process and the results of learning.

\section{References}

Aningsih, \& Zahrani, M. (2019). Peningkatan Pemahaman Konsep Siswa Pada Mata Pelajaran IPA Melalui Penerapan Model Contextual Teaching and Learning (CTL). Jurnal Pedagogik, 7(1), 48-56. https://doi.org/10.36768/Pedagogik.v2i1.28

Asmoro, B. P., \& Mukti, F. D. (2019). Peningkatan Rasa Ingin Tahu Ilmu Pengetahuan Alam Melalui Model Contextual Teaching and Learning Pada Siswa Kelas Va Sekolah Dasar Negeri Karangroto 02. Abdau: Jurnal Pendidikan Madrasah Ibtidaiyah, 2(1), 115-142. https://doi.org/10.36768/abdau.v2i1.28

Bujuri, D. A. (2018). Analisis Perkembangan Kognitif Anak Usia Dasar dan Implikasinya dalam Kegiatan Belajar Mengajar. LITERASI (Jurnal Ilmu Pendidikan), 9(1), 37. https://doi.org/10.21927/literasi.2018.9(1).3750

Dwi Mukti, F. (2019). Pengembangan Media Pembelajaran Augmented Reality (AR) di Kelas V MI Wahid Hasyim. Islamic Elementary Teacher Journal, https://doi.org/dx.doi.org/10.21043/elementary.v7i2.6351 
Elyana. (2017). Penerapan Pendekatan Keterampilan Proses Untuk Meningkatkan Aktivitas dan Hasil Belajar Siswa Pada Mata Pelajaran IPA Kelas IV di SD Negeri 18 Rejang Lebong nasional untuk menciptakan manusia yang berilmu, bertaqwa dan berbudaya manusia . Jadi , pendidik. Jurnal Pendidikan Dasar, 1(2), 108-122. https://doi.org/10.36768/abdau.v2i1.277

Fakhrurrazi, F. (2018). Hakikat Pembelajaran Yang Efektif. At-Tafkir, 11(1), 85. https://doi.org/10.32505/at.v11i1.529

Fitriyati, I., Hidayat, A., \& Munzil. (2017). Pengembangan Perangkat Pembelajaran IPA untuk Meningkatkan Kemampuan Berpikir Tingkat Tinggi dan Penalaran Ilmiah Siswa Sekolah Menengah Pertama. Jurnal Pembelajaran Sains, 1(1), 27-34.

Juwantara, R. A. (2019). Analisis Teori Perkembangan Kognitif Piaget pada Tahap Anak Usia Operasional Konkret 7-12 Tahun dalam Pembelajaran Matematika. Al-Adzka: Jurnal Ilmiah Pendidikan Guru Madrasah Ibtidaiyah, 9(1), 27. https://doi.org/10.18592/aladzkapgmi.v9i1.3011

Karlina, H. (2017). Penggunaan Media Audio-Visual Untuk Meningkatkan Kemampuan Menulis Naskah Drama. 1(April).

Mardiana, M. (2018). Penerapan Pembelajaran Ipa Berbasis Konstruktivisme Dalam Meningkatkan Sikap Ilmiah Pada Siswa Madrasah Ibtidayah. Al-Madrasah: Jurnal Pendidikan Madrasah Ibtidaiyah, 3(1), 61-80. https://doi.org/10.35931/am.v0i0.69

Oktiani, I. (2017). Kreativitas Guru dalam Meningkatkan Motivasi Belajar Peserta Didik. Jurnal Kependidikan, 5(2), 216-232. https://doi.org/10.24090/jk.v5i2.1939

Permana, M. S., \& Johar, D. (2014). Pengembangan Media Pembelajaran Interaktif Ilmu Pengetahuan Alam (IPA) Berbasis Multimedia. Jurnal Algoritma Sekolah Tinggi Teknologi Garut Jadi, 11(2), 254-263. https://doi.org/ISSN : 2302-7339

Pindo, H., \& Rinci, S. (2018). SEJ (School Education Journal) Vol. 8. No 2 Juni 2018. Meningkatkan Hasil Belajar Siswa Dengan Alat Peraga Pada Mata Pelajaran Ipa Kelas Iv Sdn Nomor 14 Simbolon Purba, 8(2), 112.

Prita, H., \& Joko, T. (2017). Augment Reality sebagai Teknologi Interaktif dalam Pengenalan Benda Cagar Budaya Kepada Masyarakat. Jurnal Simetris, 8(2), 807-812. https://doi.org/DOI: 10.24176/simet.v8i2.1614Augment Reality Sebagai Teknologi Interaktif dalam pengenalan Benda Cagar Budaya Kepada Masyarakat

Riyanti, A., \& Setyami, I. (2017). Penggunaan Media Pembelajaran Sastra. Jurnal Retorika, 10(2), $106-111$. https://doi.org/10.26858/retorika.v

Setyawan, B. (2019). Augmented Reality Dalam. 07(01), 78-90.

Suandito, B. (2017). Bukti Informal Dalam Pembelajaran Matematika. Al-Jabar : Jurnal Pendidikan Matematika, 8(1), 13. https://doi.org/10.24042/ajpm.v8i1.1160

Suwardi, I., \& Farnisa, R. (2018). Hubungan Peran Guru Dalam Proses Pembelajaran Terhadap Prestasi Belajar Siswa. Jurnal Gentala Pendidikan Dasar, 3(2), 181-202. https://doi.org/10.22437/gentala.v3i2.6758

Yuliono, T., Sarwanto, \& Rintayati, P. (2019). Keefektifan Media Pemelajaran Augmented Reality Terhadap Penguasaan Konsep Sistem Pencernaan Manusia. JPD: Jurnal Pendidikan Dasar, 4(7), 65-84. https://doi.org/doi.org/10.21009/JPD.091.06 Keefektifan 